Artikel Penelitian

\title{
Kandungan Gizi, Aktivitas Antioksidan dan Uji Organoleptik Puding Berbasis Kembang Kol (Brassica oleracea var. Botrytis) dan Strawberry (Fragaria $x$ ananassa) Nutrient content, antioxidant activity and Organoleptic test of Pudding Based on Cauliflower (Brassica oleracea var. Botrytis) and Strawberry (Fragaria $x$ ananassa)
}

Luh Putu Prema Wadhani ${ }^{*}$, Nani Ratnaningsih², Badraningsih Lastariwati2

${ }^{1}$ Program Pascasarjana, Pendidikan Kesejahteraan Keluarga, Univesitas Negeri Yogyakarta, Yogyakarta

2Fakultas Teknik, Pendidikan Tata Boga, Universitas Negeri Yogyakarta, Yogyakarta

*Korespondensi dengan penulis (luhputu.2018@student.uny.ac.id)

Artikel ini dikirim pada tanggal 12 Januari 2020 dan dinyatakan diterima tanggal 30 November 2020. Artikel ini juga dipublikasi secara online melalui https://ejournal2.undip.ac.id/index.php/jatp. Hak cipta dilindungi undang-undang. Dilarang diperbanyak untuk tujuan komersial.

Diproduksi oleh Indonesian Food Technologists ${ }^{\circledR}$ (C2021

\begin{abstract}
Abstrak
Masih kurangnya konsumsi sayuran dan buah yang terjadi di Indoensia saat ini. Kembang kol dan strawberry merupakan sayur dan buah yang mengandung zat gizi dan antioksidan yang berperan penting dalam mengurangi resiko timbulnya berbagai masalah kesehatan. Salah satu upaya dalam meningkatkan konsumsi buah dan sayur dapat dilakukan dengan cara pemanfaatan kembang kol dan strawberry secara bersamaan yang diolah menjadi produk pangan basah seperti puding. Penelitian ini bertujuan untuk menganalisis kandungan gizi, aktivitas antioksidan dan uji organoleptik pada puding berbasis kembang kol dan strawberry. Metode penelitian ini menggunakan metode penelitian dan pengembangan (Research and Development) dengan model 4D. Penelitian ini terdiri dari proses pembuatan puding dengan campuran 30\% kembang kol dan $25 \%$ strawberry, analisis kandungan gizi puding yang terdiri dari analisa kadar air, kadar abu, protein, lemak, karbohidrat, kalium, natrium, analisis aktivitas antioksidan dan uji organoleptik. Hasil analisis kandungan air, abu, protein, lemak, karbohidrat, natrium dan kalium masing masing sebesar $80,82 \%, 2,35 \%, 8,20 \%, 0,18 \%, 89,18 \%, 380,59 \mathrm{mg}$, dan 278,09 $\mathrm{mg}$, sedangkan aktivitas antioksidan sebesar $229,23 \%$. Puding ini dapat diterima oleh panelis dengan nilai terhadap sifat keseluruhan sebesar 3,7 . Kesimpulannya, kembang kol dan strawberry dapat digunakan sebagai formula dalam pembuatan puding yang memiliki kandungan sayuran dan buah.
\end{abstract}

Kata kunci: kandungan gizi, aktivitas antioksidan, pudding, kembang kol, strawberry

\section{Abstract}

The lack of consumption of vegetables and fruits is happening in Indonesia at this time. Cauliflower and strawberry are vegetables and fruits that contain nutrients and antioxidants which can play an important role in reducing the risk of various health problems. One effort to increase consumption of fruits and vegetables can be done by utilizing cauliflower and strawberries that are processed into food such as pudding. This study aims to analyze the nutritional content, antioxidant activity and organoleptic tests on cauliflower and strawberry-based pudding. This research used research and development methods using 4D model. This research applied mixture of $30 \%$ cauliflower and $25 \%$ strawberry in pudding. Nutrients analysis wer done on water content, ash content, protein, fat, calcium, potassium, sodium, antioxidant activity. Organoleptic analysis was also conducted in this research. The results of the analysis of water, ash, protein, fat, carbohydrate, sodium and potassium content were $80.82 \%, 2.35 \%$, $8.20 \%, 0.18 \%, 89.18 \%, 380.59 \mathrm{mg}, 278.09 \mathrm{mg}$, respectively, while the antioxidant activity achieved $229.23 \%$. This pudding could be accepted by panelists with a total value of 3.7. In conclusion, cauliflower and strawberry could be used in making vegetable and fruit rich pudding.

Keywords: Nutrient content, antioxidant activity, pudding, cauliflower, strawberry

\begin{abstract}
Pendahuluan
Indonesia merupakan negara agraris dan beriklim tropis yang memiliki kekayaan sumber daya alam termasuk tanaman sayuran serta buah-buahan. Keanekaragaman sayuran dan buah-buahan membuat Indonesia dikenal sebagai negara produsen tertinggi penghasil sayuran dan buah-buahan (Zurriyati dan Dahono, 2016). Namun, keadaan tersebut tidak membuat masyarakat Indonesia gemar untuk mengkonsumsi sayuran dan buah. Hasil Riset Kesehatan Dasar 2018 memperoleh sebanyak 95,5\% penduduk Indonesia memiliki proporsi konsumsi buah dan sayur yang $<5$ porsi per hari. Keadaan ini membuktikan bahwa masih kurangnya konsumsi
\end{abstract}

buah dan sayur pada penduduk Indonesia saat ini. Terpenuhinya asupan vitamin dan mineral yang terdapat dalam sayuran dan buah-buahan secara optimal pada setiap individu sangat diperlukan oleh tubuh. Kandungan vitamin, mineral dan antioksidan yang terkandung dalam sayuran dan buah-buahan memiliki peranan penting yang dapat mengurangi resiko timbulnya berbagai masalah kesehatan terkait gizi seperti diabetes mellitus, gagal ginjal dan obesitas (Hermina dan Prihatini, 2016).

Kembang kol (Brassica oleracea var. botrytis) atau yang sering disebut sebagai bunga kubis merupakan salah satu tanaman sayuran yang memiliki batang lunak yang banyak tumbuh pada 
dataran tinggi di Indonesia dengan hasil produksi mencapai 12,14 ton/Ha pada tahun 2018 (Badan Pusat Statistik, 2018). Kembang kol memiliki kandungan zat gizi yang terdiri dari kalsium, magnesium, kalium, fosfor dan lemak jenuh yang sangat rendah serta senyawa yang bermanfaat bagi kesehatan tubuh. Kandungan senyawa sulforafan, indol dan antioksidan dalam kembang kol dapat secara efektif mencegah terjadinya kerusakan pada ginjal, kandung kemih, sebagai anti kanker, anti mikrobia, dan diuretik (Baloch et al., 2015; Uher et al., 2017).

Pemenuhan kebutuhan zat gizi juga dapat dilakukan dengan mengkonsumsi berbagai buah, salah satunya adalah buah Strawberry (Fragaria $x$ ananassa) yang kaya akan provitamin $A$ dan $C$, kalsium, fosfor, zat besi, natrium, kalium dan magnesium serta asam elagik yang merupakan senyawa antitoksik dan anti radikal bebas, anti karsinogenik yang baik bagi kesehatan tubuh (Astuti et al. 2015). Strawberry juga dapat diolah sebagai jenis makanan basah dalam bentuk puding.

Puding merupakan salah satu hidangan penutup yang terbuat dari berbagai bahan makanan yang terdiri dari agar-agar, susu, gula dan air yang diolah dengan cara direbus (Misnaiyah et al., 2018). Bebarapa hasil penelitian yang telah dilakukan sebelumnya menunjukkan bahwa beberapa bahan tambahan yang dapat digunakan dalam campuran puding dapat berupa brokoli dan rumput laut (Misnaiyah et al., 2018; Rosalita, 2018) Namun, pengembangan pada pengolahan puding yang dilakukan dengan mengkombinasikan buah dan sayur yang salah satunya menggunakan kembang kol dan strawberry ke dalam olahan puding, belum pernah dilakukan dan dikembangkan. Penelitian ini bertujuan untuk menganalisis kandungan gizi, aktivitas antioksidan dan organoleptik dari produk pengembangan puding berbasis kembang kol dan strawbbery. Penelitian ini diharapkan mampu memberikan referensi bagi masyarakat untuk dapat mengolah makanan yang sehat dari sayuran dan buah, sehingga pemenuhan asupan zat gizi vitamin, mineral dan senyawa yang baik bagi kesehatan tubuh dapat terpenuhi secara optimal.

\section{Materi dan Metode}

Materi

Bahan utama yang digunakan dalam pembuatan puding terdiri dari kembang kol segar, strawberry segar, susu skim, gula pasir, jelly plan, dan tepung maizena. Peralatan utama yang digunakan dalam pembuatan puding terdiri dari kompor, panci, dan blender yang digunakan untuk menghaluskan kembang kol dan strawberry, serta peralatan saji. Alat dan bahan yang digunakan dalam pengujian organopetik yaitu kertas kuesioner penilaian, alat tulis (pulpen), air mineral, sendok, dan tisu.

\section{Metode}

Penelitian ini dilaksanakan selama periode September hingga Desember 2019. Penelitian ini dimulai dengan pembuatan sari kembang kol dan strawberry, pembuatan formulasi optimal pada puding dengan campuran kembang kol dan strawberry, analisis organoleptik dengan parameter warna, rasa, aroma, tekstur dan sifat keseluruhan. Penelitian ini juga menganalisis zat gizi yaitu uji proksimat yang terdiri dari kadar abu, kadar air, protein, lemak, dan karbohidrat. Pengujian zat gizi lain juga dilakukan pada kandungan kalium, natrium serta aktivitas antioksidan.

Penelitian ini menggunakan desain Penelitian dan pengembangan (Research and Development) dengan model 4D yang terdiri dari define (analisis kebutuhan), design (perancangan), development (pengembangan), dan disseminate (penyebarluasan). Pada tahap Define, peneliti merumuskan produk pudding dengan menggunakan resep dasar pudding dengan memperhatikan beberapa aspek seperti rasa, aroma, warna dan tekstur dalam pembuatan puding tersebut. Pada tahap Design, dilakukan modifikasi pada resep puding tersebut dengan membuat campuran $30 \%$ kembang kol dan $25 \%$ strawberry. Tahap selanjutnya yaitu Development dengan melakukan uji validitas produk pengembangan puding tersebut oleh dosen ahli serta merancang kemasan puding. Tahap terakhir yaitu Disseminate yaitu dengan melakukan uji mutu sensoris serta kandungan gizi pada laboratorium kimia yaitu laboratorium Chemix Pratama (Mulyatiningsih, 2011).

\section{Proses Pembuatan Pudding}

Proses pembuatan puding dimulai dari pemilihan serta sortasi kembang kol maupun strawberry yang tidak cacat atau busuk dan dengan ukuran serta warna yang seragam. Selanjutnya dilakukan tahap pencucian dengan menggunakan air mengalir untuk menghilangkan kemungkinan sisa kotoran yang melekat pada kembang kol maupun strawberry. Tahap selanjutnya yaitu memotong kembang kol maupun strawberry menjadi bagianbagian kecil. Proses ini dilakukan agar memudahkan dalam proses penghalusan kembang kol maupun strawberry pada blender. Selanjutnya kembang kol di kukus selama tidak lebih dari 2 menit guna mempertahankan warna, mengurangi kalium serta menghilangkan aroma khas dari kembang kol. Selanjutnya kembang kol maupun strawberry dihaluskan dengan menggunakan blender secara bergilir atau tidak dicampur. Setelah kedua bahan halus maka tahap selanjutnya yaitu memasak puding dengan campuran kembang kol dan strawberry serta campuran bahan lainnya seperti gula pasir, susu skim, dan jelly plan. Pembuatan puding ini terdiri dari 4 lapisan (layer) dalam 1 cup puding. Lapisan pertama dan ketiga dibuat dengan campuran strawberry, kembang kol, susu skim, gula pasir dan jelly plan, lapisan kedua dan keempat dibuat dengan menggunakan campuran kembang kol, gula pasir, 
susu skim dan tepung maizena. Adapun resep standar dan produk penelitian, dapat dilihat pada Tabel 1.

Tabel 1. Resep acuan dan produk penelitian

\begin{tabular}{lll}
\hline Bahan & Acuan & Produk Penelitian \\
\hline Bubuk Agar-Agar & $10 \mathrm{~g}$ & $10 \mathrm{~g}$ \\
Susu Skim & - & $300 \mathrm{ml}$ \\
Susu Full Cream & $750 \mathrm{ml}$ & - \\
Gula pasir & $100 \mathrm{~g}$ & $100 \mathrm{~g}$ \\
Garam & $1 / 2 \mathrm{sdt}$ & $1 / 2 \mathrm{sdt}$ \\
Ekstrak Kembang Kol & - & $250 \mathrm{ml}$ \\
Ekstrask Strawberry & - & $200 \mathrm{ml}$
\end{tabular}

Keterangan: Produk acuan dilakukan berdasarkan penelitian terdahulu (Kusumawati et al., 2020).

\section{Analisis Organoleptik}

Analisis uji organoleptik pada penelitian ini dilakukan dengan menguji hedonik produk dengan menggunakan borang uji hedonik. Pengujian organoleptik ini dilakukan dengan menggunaka metode skoring pada setiap penilaian. Panelis yang digunakan dalam menguji hedonik yaitu sebanyak 30 panelis agak terlatih yang berasal mahasiswa pascasarjana Univesitas Negeri Yogyakarta dan masyarakat umum. Pengujian hedonik ini dilakukan dengan menggunakan 4 skala penilaian yaitu (1) sangat tidak suka, (2) tidak suka, (3) suka, dan (4) sangat suka. Produk dianggap diterima jika hasil analisis uji hedonik lebih besar dari skala 2 (Suryono et al., 2018).

\section{Analisis Kadar Air}

Pengukuran kadar air yang dilakukan pada penelitian ini menggunakan metode oven. Sampel yang digunakan adalah sebanyak 1-2 g (AOAC, 2005).

\section{Analisis Kadar Abu}

Pengukuran kadar abu dalam penelitian ini dilakukan dengan menggunakan metode gravimetri dengan menggunakan sampel sebanyak 3-5 g (AOAC, 2005).

\section{Analisis Kadar Protein}

Analisa protein yang digunakan dalam penelitian ini pada menggunakan metode Mikro Kjeidal yang menggunakan sampel sebanyak $0.2 \mathrm{~g}$ (AOAC, 2005).

\section{Analisis Kadar Lemak}

Analisa lemak dalam penelitian ini mengggunakan metode Mojonier. Prosedur ini dilakukan dengan menggunakan $5 \mathrm{~g}$ sampel (AOAC, 2005).

\section{Analisis Kadar Karbohidrat}

Kadar karbohidrat ditentukan dengan by difference yaitu dilakukan dengan menghitung hasil pengurangan $100 \%$ pada hasil kadar air, kadar abu, kadar protein, kadar lemak, dan kadar serat kasar, sehingga penentuan kadar karbohidrat tergantung pada hasil pengukuran kadar zat gizi lainnya (Akbar et al., 2019).

\section{Analisis Kalium}

Analisis kandungan kalium yang dilakukan dalam penelitian ini dilakukan dengan menggunakan metode AAS (Atomic Absorbtion Spectrofotometry) dengan menggunakan sampel sebanyak $5 \mathrm{~g}$ (Kartika et al., 2019).

\section{Analisis Natrium}

Analisa kandungan natrium dilakukan dengan metode titrasi argentometri dengan menggunakan sampel sebanyak $5 \mathrm{~g}$ sesuai dengan prosedur yang dilakukan oleh peneliti sebelumnya (Kartika et al., 2019).

Analisis Aktivitas Antioksidan

Analisa aktivitas antioksidan dalam penelitian ini dilakukan dengan menggunakan metode DPPH dengan menggunakan sampel sebanyak $1 \mathrm{~g}$. Metode ini dilakukan berdasarkan pada peneliti terdahulu (Sedjati et al., 2017).

\section{Analisis Statistik}

Data yang diperoleh selanjutnya dianalisis dengan menggunakan Microsoft Excel 2013 dan SPSS 16.0. Data kandungan gizi dan organoleptik yang diperoleh dianalisis dengan menggunakan uji paired $t$-test dengan taraf signifikansi $5 \%$.

\section{Hasil dan Pembahasan \\ Uji Organoleptik}

Beberapa faktor yang dapat mempengaruhi hasil uji organoleptik dapat berasal dari faktor internal maupun eksternal (Arysanti et al., 2019). Uji organoleptik pada penelitian ini dilakukan dengan menguji dua sampel yaitu pada produk acuan yang berasal dari puding komersial dan produk penelitian ini. Adapun hasil penilaian dari uji organoleptik pada kedua sampel dapat dilihat pada Tabel 2.

Tabel 2. Hasil analisis uji organoleptik puding pada produk acuan dan produk penelitian

\begin{tabular}{lcc}
\hline Parameter & Acuan & Produk Penelitian \\
\hline Warna & $3,2 \pm 0,626^{\mathrm{b}}$ & $3,8 \pm 0,379^{\mathrm{b}}$ \\
Aroma & $3,2 \pm 0,626^{\mathrm{b}}$ & $3,6 \pm 0,621^{\mathrm{b}}$ \\
Rasa & $3,1 \pm 0,647^{\mathrm{b}}$ & $3,8 \pm 0,345^{\mathrm{b}}$ \\
Tekstur & $3,6 \pm 0,490^{\mathrm{a}}$ & $3,7 \pm 0,466^{\mathrm{a}}$ \\
Overall & $3,4 \pm 0,507^{\mathrm{b}}$ & $3,7 \pm 0,430^{\mathrm{b}}$ \\
\hline
\end{tabular}

Keterangan: superskrip yang berbeda pada baris yang sama menunjukkan adanya perbedaan nyata $(p<0,05)$ dengan menggunakan uji paired t-test

Berdasarkan hasil uji organoleptik (Tabel 2) menunjukkan bahwa produk penelitian adalah lebih disukai panelis jika dilihat dari parameter warna, aroma, rasa, tekstur dan sifat keseluruhan (overall). Warna, rasa, aroma dan tekstur makanan menjadi faktor penting yang harus diperhatikan dalam seni penyajian makanan sehingga makanan tersebut dapat memberikan dan menggugah selera bagi yang 
menikmatinya (Iswendi et al., 2019). Penambahan kembang kol dan strawberry yang ada dalam puding pengembangan ini membuat warna puding menjadi lebih menarik, sehingga hal tersebut berpengaruh terhadap daya terima serta tingkat kesukaan.

Hasil uji paired t-test pada parameter warna menunjukkan bahwa terdapat perbedaan warna pada produk acuan dan produk penelitian. Hal ini membuktikan bahwa pudding produk penelitian dengan penambahan kembang kol dan strawberry makin dapat diterima oleh panelis. Hasil penelitian ini sejalan dengan penelitian Arysanti et al., (2019) yang menunjukkan bahwa semakin tinggi penambahan pewarnaan dengan menggunakan buah naga pada puding dapat meningkatkan daya terima dari produk puding tersebut.

Aroma yang ditimbulkan oleh suatu produk makanan dan minuman menjadi daya tarik tersendiri bagi penerimanya (Iswendi et al., 2019). Namun, penilaian aroma menjadi penilaian yang paling sulit dinilai dalam uji organoleptik (Misnaiyah et al., 2018). Penambahan kembang kol dan strawberry yang ada pada produk puding ini memberikan efek aroma yang dapat diterima oleh panelis. Hasil uji paired t-test menunjukkan bahwa terdapat perbedaan pada aroma produk acuan dan produk penelitian. Hal tersebut terjadi karena perbedaan aroma susu yang ada pada produk acuan berbeda dengan aroma khas kembang kol dan strawberry pada produk penelitian. Parameter lain, seperti rasa, dapat menjadi stimulus yang muncul diakibatkan oleh komponen atau senyawa kimia volatil dan non volatil yang ada dalam makanan (Arysanti et al., 2019). Hasil uji paired t-test menunjukkan bahwa terdapat perbedaan rasa pada produk acuan dan penelitian. Hal tersebut terjadi karena senyawa volatil khas yang dihasilkan strawberry dan menjadi daya tarik pada produk penelitian.

Tekstur yang dihasilkan dalam sebuah produk makanan merupakan salah satu sifat fisik yang dapat menentukan cita rasa dalam makanan. Hasil uji paired t-test pada tekstur produk puding menunjukkan bahwa tidak terdapat perbedaan yang signifikan terhadap produk puding acuan dan produk puding penelitian. Hal ini dikarenakan pada kedua produk menggunakan bahan agar-agar yang dapat menghasilkan tekstur yang lembut dan kenyal pada kedua produk. Kandungan gel yang ada dalam agar-agar dalam proses pembuatan puding dapat menghasilkan tekstur puding yang lembut dan kenyal (Iswendi et al., 2019) dan bukan karena adanya penambahan buah atau sayur, sebagaimana hasil penelitian Tamimi et al., (2019) yang menunjukkan bahwa penambahan kulit jeruk dan semangka tidak memberikan pengaruh terhadap tekstur puding. Selain itu, dilihat dari penilaian dan uji perbedaan (Tabel 2) pada sifat keseluruhan (Overall) menunjukkan bahwa terdapat perbedaan yang signifikan antara produk acuan dan produk penelitian.

\section{Analisis Kandungan Gizi}

Hasil analisis statistik kadar air (Tabel 3) menunjukkan adanya perbedaan yang nyata pada kedua sampel, selain itu hasil tersebut menunjukkan bahwa nilai rerata kadar air tertinggi terdapat pada produk penelitian yaitu sebesar $80,82 \%$. Kadar air pada penelitian ini lebih tinggi dari kadar air puding pada penelitian China et al. (2019) yaitu sebesar $71,89 \%$. Tingginya kadar air pada produk puding ini dikarenakan bahan pangan kembang kol yang memiliki kandungan kadar air sebanyak 90,62\% (Mansour et al., 2015) dan strawberry sebanyak 92,4\% (Sandulachi dan Tatarov, 2012). Hal ini sesuai dengan Mansour et al. (2015) yang meneliti kandungan kadar air yang terdapat pada kembang kol yang dimasak dengan cara pemanasan, memiliki kandungan kadar air yang cukup tinggi yaitu sebesar $93,30 \%$.

Kadar abu merupakan suatu unsur yang membentuk bahan ekstrak tanpa adanya nitrogen dan dapat mempengaruhi komposisi bahan organik (Utama et al., 2019). Kadar abu juga merupakan ukuran yang digunakan untuk mengetahui jumlah total dari mineral yang terdapat dalam bahan pangan (Susanti et al., 2020). Hasil penelitian ini menunjukkan bahwa tidak terdapat perbedaan yang nyata (Tabel 3) pada kadar abu dalam kedua sampel dengan nilai rerata pada produk pengembangan sebesar $2,35 \%$. Menurut China et al. (2019) tinggi dan rendahnya kadar abu dalam produk pangan sangat dipengaruhi oleh metode dalam proses pemasakan, selain itu, kadar abu juga berkorelasi terhadap kandungan mineral yang ada dalam produk pangan tersebut.

Tabel 3. Kandungan gizi puding acuan dan produk penelitian

\begin{tabular}{lcc}
\hline Kandungan Gizi & Acuan & Produk Penelitian \\
\hline Kadar Air (\%) & $77,47 \pm 0,103^{\mathrm{a}}$ & $80,82 \pm 0,004^{\mathrm{b}}$ \\
Kadar Abu (\% BK) & $3,84 \pm 0,388^{\mathrm{a}}$ & $2,35 \pm 0,014^{\mathrm{a}}$ \\
Protein $(\% \mathrm{BK})$ & $10,89 \pm 0,777^{\mathrm{a}}$ & $8,20 \pm 0,424^{\mathrm{b}}$ \\
Lemak $(\% \mathrm{BK})$ & $0,24 \pm 0,077^{\mathrm{a}}$ & $0,18 \pm 0,007^{\mathrm{a}}$ \\
Karbohidrat $(\% \mathrm{BK})$ & $85,01 \pm 0,386^{\mathrm{a}}$ & $89,18 \pm 0,028^{\mathrm{b}}$ \\
Natrium & $518,46 \pm 51,25^{\mathrm{a}}$ & $380,59 \pm 31,78^{\mathrm{a}}$ \\
(mg/100 g BK) & & \\
Kalium & $372,88 \pm 49,15^{\mathrm{a}}$ & $278,09 \pm 14,91^{\mathrm{a}}$
\end{tabular}

(mg/100 g BK)

Aktivitas Antioksidan $\quad 229,20 \pm 2,26^{a} \quad 229,23 \pm 1,49^{a}$

(\% BK)

Keterangan: superskrip yang berbeda pada baris yang sama menunjukkan adanya perbedaan nyata $(p<0,05)$ dengan menggunakan uji paired t-test

Hasil analisis kandungan protein pada penelitian ini menujukkan bahwa kandungan protein produk pengembangan adalah sebesar $8,20 \%$. Hasil tersebut juga menunjukkan adanya perbedaan yang nyata pada kandungan protein (Tabel 3) pada kedua produk puding. Hal ini sesuai dengan kandungan protein yang terdapat dalam kembang kol yaitu sebanyak $4 \mathrm{~g} / 100 \mathrm{~g}$ bahan sedangkan protein yang terkandung dalam strawberry sebesar $0,7 \mathrm{~g} / 100 \mathrm{~g}$ bahan (Misnaiyah et al., 2018; Astuti et al 2015). Protein merupakan salah satu zat gizi yang sangat diperlukan oleh tubuh yang digunakan dalam 
pembentukan sel dan metabolisme sel (Jauhari et al, 2019). Pemenuhan zat gizi protein yang tinggi pada anak dan remaja sangat dibutuhkan dalam membantu pertumbuhan dan perkembangannya (Jauhari et al, 2019). Namun, pada beberapa keadaan seperti pada penderita gagal ginjal pembatasan dalam pemberian protein sangat perlu diperhatikan, sehingga pemenuhan protein dapat diberikan dalam jumlah yang rendah (Almatsier, 2010). Dengan jumlah protein yang terkandung dalam kembang kol dan strawberry yang ada dalam pengembangan puding pada penelitian ini, maka puding ini sangat cocok dijadikan sebagai pelengkap dalam menu makanan untuk kesehatan yang dapat dikonsumsi oleh anak hingga lansia, maupun beberapa penderita penyakit seperti gagal ginjal yang membutuhkan protein dengan jumlah terbatas.

Secara umum, prinsip dasar pada pemenuhan asupan lemak yang seimbang yaitu sebesar $20-25 \%$ dari total kebutuhan gizi. Hasil penelitian ini menunjukkan bahwa tidak terdapat perbedaan yang nyata pada kedua sampel (Tabel 3 ). Hal ini sesuai dengan Mansour et al. (2015) yang meneliti kandungan lemak pada kembang kol yang telah dikukus, sangatlah rendah, yaitu sebesar $0,16 \%$. Selanjutnya, kandungan karbohidrat menunjukkan adanya perbedaan yang nyata dengan kandungan karbohidrat pada produk penelitian mencapai $89,18 \%$. Hal ini sejalan dengan penelitian Chidi et al. (2019) yang memperoleh hasil bahwa kandungan karbohidrat sebanyak $70-80 \%$ dalam berat kering dalam puding, dicapai karena adanya berbagai subtitusi didalam puding tersebut.

Natrium merupakan salah satu mineral yang berperan penting dalam pemeliharaan volume plasma dan menjaga keseimbangan asam dan basa (Lage et al., 2019). Kecukupan asupan natrium yang baik dalam tubuh sebaiknya tidak lebih dari 2000 mg per hari (Prihatini et al., 2016). Namun, pada beberapa penderita penyakit kardivaskuler, gagal ginjal dan hipertensi pembatasan asupan natrium sangat perlu dilakukan yaitu <4 g/hari (Zadeh et al., 2017). Hasil analisis kandungan natrium (Tabel 3 ) pada penelitian ini menunjukkan bahwa tidak terdapat perbedaan yang nyata pada kedua sampel. Sebagaimana dapat dilihat pada Tabel 2, kandungan natrium pada produk pengembangan puding cukup rendah yaitu sebesar $380,59 \mathrm{mg}$. Kandungan natrium dalam produk pengembangan ini masih termasuk dalam jumlah natrium yang aman untuk dikonsumsi terutama untuk penderita gagal ginjal dan hipertensi. Hal ini juga sesuai dengan penelitian Mansour et al. (2015) yang memperoleh bahwa kandungan natrium dalam kembang kol yang telah dikukus menghasilkan 350,44 mg natrium dan Khan et al. (2010) memperoleh kandungan natrium strawberry sebesar 28,98 mg, sebuah nilai yang sangat kecil jika digunakan sebagai bahan baku puding.

Kalium merupakan mineral penting yang berperan dalam mengatur cairan intraseluler dan menyeimbangkan keadaan $\mathrm{pH}$ dan osmolalitas (Lage et al., 2019). Kurangnya kalium yang ada dalam tubuh dapat disebabkan oleh ekskresi yang terjadi secara berlebihan oleh ginjal maupun keadaan tertentu seperti muntah dan diare yang berlebihan (Cupisti et al, 2018). Pada kerusakan ginjal, kalium menjadi salah satu mineral yang harus diperhatikan (Cases et al, 2019). Namun, peningkatan asupan kalium yang berlebihan dalam tubuh dapat meningkatkan resiko hyperkalemia (Saharuddin et al, 2018). Menurut Cupisti et al. (2018) rekomendasi pemberian konsumsi kalium pada keadaan seseorang yang sehat adalah sebesar 3,9 g/hari, sedangkan pada keadaan tertentu seperti penderita gagal ginjal dan dengan adanya substansi proteinuria, diberikan pembatasan konsumsi kalium sebesar kurang dari 3 g/hari. Kandungan kalium pada produk penelitian ini mencapai 278,09 mg/100 g (Tabel 3), sehingga kandungan kalium pada produk ini masih dalam batasan yang normal yaitu dibawah $3 \mathrm{~g} / 100 \mathrm{~g}$ puding. Selain itu, hasil analisis menunjukkan bahwa tidak terdapat perbedaan yang nyata pada kedua sampel (Tabel 3). Hal ini dikarenakan kandungan kalium pada bahan baku yang digunakan dalam pembuatan produk tersebut, dinilai sangat kecil pengaruhnya.

\section{Aktivitas Antioksidan}

Aktiosidan merupakan senyawa yang memiliki peranan penting dalam menghambat reaksi oksidatif dalam tubuh yang dapat menimbulkan berbagai penyakit (Dennis et al., 2017). Peningkatan keadaan stress oksidatif dapat terjadi pada beberapa penyakit seperti gagal ginjal, obesitas dan kanker (Yosika et al., 2020). Peningkatan stress oksidatif yang terjadi dalam tubuh dan dapat menurunkan sistem pertahanan tubuh sehingga dibutuhkan antioksidan (Chen and Siriki, 2015). Secara umum, buah strawberry memiliki kandungan senyawa antioksidan yang terdiri dari antosianin dan ellgatanin yang berkhasiat sebagai detoksifikasi karsinogenik dalam tubuh (Widyastuti dan Desfita, 2020). Selain itu, hasil penelitian Nisa et al. (2020) juga menunjukkan bahwa semakin tinggi konsentrasi strawberry yang digunakan dalam pembuatan selai maka semakin tinggi kadar vitamin C dan antioksidan dalam produk selai tersebut.

Berdasarkan hasil analisis statistik yang telah dilakukan, tidak terdapat perbedaan yang nyata pada kedua sampel tersebut. Namun, kandungan aktivitas antioksidan yang ada dalam produk pengembangan ini dinilai cukup banyak yaitu sebesar 229,23\% dalam berat kering, sehingga dilihat dari kandungan aktivitas antioksidan tersebut, maka produk ini dinilai dapat menghambat peningkatan stress oksidatif yang terjadi dalam tubuh.

\section{Kesimpulan}

Berdasarkan hasil penelitian ini, produk puding berbasis kembang kol dan strawberry dinilai memiliki kandungan gizi yang spesifik dan lebih dapat diterima panelis jika dibandingkan dengan produk puding acuan. Disamping itu, puding hasil penelitian ini, 
memiliki aktivitas antioksidan yang dinilai tinggi yang tidak kalah dari puding acuan.

\section{Daftar Pustaka}

Akbar, C.I., Arini, F.A., Fauziyah, A. 2019. Teh rambut jagung dengan penambahan daun stevia sebagai alternatif minuman fungsional bagi penderita diabetes melitus tipe 2. Jurnal Aplikasi Teknologi Pangan 8(2):67-73. DOI: 10.17728/jatp.3122.

Almatsier, Sunita. 2010. Prinsip Dasar IImu Gizi. PT. Gramedia Pustaka Utama, Jakarta.

Arysanti, R. D., Sulistiyani, S., Rohmawati, N. 2019. Indeks glikemik, kandungan gizi, dan daya terima puding ubi jalar putih (Ipomoea batatas) dengan penambahan buah naga merah (hylocereus polyrhizus). Jurnal Amerta Nutrition 3(2):107-113.

DOI: 10.20473/amnt.v3i2.2019.107-113.

Association of Official Analytical Chemists (AOAC). 2005. Official methods of analysis of the association of analytical chemists. AOAC, Inc, Virginia.

Astuti, D.P., Rahayu, A., Ramdani, H. 2015. Pertumbuhan dan produksi stroberi (Fragaria vesca l.) Pada volume media tanam dan frekuensi pemberian pupuk NPK berbeda. Jurnal Agronida 1(1):46-56. DOI: 10.30997/jag.v1i1.138.

Badan Pusat Statistik. 2018. Statistik tanaman sayuran dan buah-buahan semusim indonesia. Jakarta: Badan Pusat Statistik Indonesia.

Baloch., Bux, A., Xiaodong, X., Saghir, A.S. 2015. Proximate and mineral compositions of dried cauliflower (Brassica oleracea I.) Grown in sindh, pakistan. Journal of Food and Nutrition Research 3(3):213-19. DOI: 10.12691/jfnr-3-314.

Cases, A., Cigarrán-Guldrís, S., Mas, S., GonzalezParra, E. 2019. Vegetable-based diets for chronic kidney disease? It is time to reconsider. Jurnal Nutrients 11(1263):1-26. DOI:10.3390/nu11061263.

Chen, J., Siriki, R. 2015. Antioxidants therapy for patients with chronic kidney disease: a question of balance. American Journal of Nephrology 42(4):318-19. DOI: 10.1159/000441628.

Chidi, Anosike, F., Nwagu, K.E., Ekwu, F., Nweke, F.N., Nwoba, S.T., Onuegbu, R.N., Enwere, E.N. 2019. Proximate composition and sensory properties of ukpo oka: a steamed maize pudding formulated from maize and african yam bean flour. Pakistan Journal of Nutrition 18(8):795-99. DOI: 10.3923/pjn.2019.795.799.

China, Mercy, Nua, Deedam., Patricia M., Christabel, P. 2019. Proximate composition and sensory assessment of beans pudding prepared using two different cooking methods. Research Journal of Food Science and Nutrition 4(2):5864. DOI: 10.31248/rifsn2019.069.

Cupisti, Adamasco, C.P., Kovesdy, Claudia D.A.,
Kamyar, Zadeh. 2018. Dietary approach to recurrent or chronic hyperkalaemia in patients with decreased kidney function. Journal Nutrients 10(3):1-15. DOI: 10.3390/nu10030261.

Dennis, Joanne M., Paul K.W. 2017. Protective role for antioxidants in acute kidney disease. Journal Nutrients 9(7):1-25. DOI: 10.3390/nu9070718.

Hermina, Prihatini, S. 2016. Gambaran konsumsi sayur dan buah penduduk indonesia dalam konteks gizi seimbang: analisis lanjut survei konsumsi makanan individu (SKMI) 2014. Buletin Penelitian Kesehatan 44(3):205-218. DOI:10.22435/bpk.v44i3.5505.205-218.

Iswendi, Yusmaita, E., Pangestuti, A.D. 2019. Uji organoleptik sari jagung di laboratorium kimia FMIPA UNP. Jurnal IImiah Pengabdian kepada Masyarakat 19(2): 45-53. DOI:10.2403/sb.0100.

Jauhari, M. T., Santoso, Anantanyu, S. 2019. Asupan protein dan kalsium serta aktivitas fisik pada anak usia sekolah dasar. Jurnal IImu Gizi Indonesia 2(2):79-88. DOI:10.35842/ilgi.v2i2.86

Kartika, A.G.D., Pratiwi, W.S.W., Indriyawati, N., Jayanthi., Wiwid. 2019. Analisis kadar magnesium dan kalium pada garam rich minerals. Journal of Science and Technology 12(1):1-4.

DOI: 10.21107/rekayasa.v12i1.5094.

Kementerian Kesehatan Badan Penelitian dan Pengembangan Kesehatan. 2018. Hasil Utama Riskesdas 2018.

Khan, M.N., Anila S., Sadaf, B., Farooq, W. 2010. Physicochemical characterization of the strawberry samples on regional basis using multivariate analysis. International Journal of Food Properties 13(4):789-799. DOI: 10.1080/10942910902894914.

Kusumawati, E., Koro, S., Bana, T. 2020. Pengaruh substitusi yoghurt dan tepung kacang hijau (Phaseolus radiatus) terhadap penilaian organoleptik, kandungan protein dan kalsium puding silky sebagai makanan tambahan alternatif untuk anak stunting. Jurnal Sains dan Teknologi Pangan 5(3):2840-2850. DOI:10.33772/jstp.v5i3.13103.

Lage, M.D., Ningsih, P., Sakung, J. 2019. Analisis kandungan kalium, labu siam (Sechium edule sw) Dari desa Sedoa, kecamatan Lore Utara, kabupaten magnesium dan natrium ekstrak buah poso. Jurnal Akademika Kimia 8(1): 24775185.

DOI:10.22487/j24775185.2019.v8.i1.2745.

Mansour, A.A., Nahed, M.E., Laila, A., Shekib, Magda, S., Sharara. 2015. Effect of domestic processing methods on the chemical composition and organoleptic properties of broccoli and cauliflower. American Journal of Food and Nutrition 3(5):125-130. DOI: 
10.12691/AJFN-3-5-3.

Misnaiyah, Indani, Kamal, R. 2018. Daya terima konsumen terhadap puding brokoli (brassica oleracea). Jurnal IImiah Pendidikan Kesejahteraan Keluarga 3(1):54-62. DOI: 10.1017/CBO9781107415324.004.

Mulyatiningsih, E. 2011. Metode Penelitian Terapan Bidang Pendidikan. Yogyakarta: Penerbit Alfabeta.

Nisa, S.R., Santoso, H., Syauqi, A. 2020. Analisis kadar vitamin c pada selai stroberi (fragaria $s p$ ) buah naga (Hylocereus costaricensis). Jurnal IImiah Sains Alami 2(2):1-7. DOI: 10.33474/j.sa.v2i2.3382.

Prihatini, S., Diana, J.E., Hermina. 2016. Kontribusi jenis bahan makanan terhadap konsumsi natrium pada anak usia 6-18 tahun di indonesia. Jurnal Penelitian Gizi dan Makanan 39(1):55-63.

DOI: 10.22435/pgm.v39i1.5973.55-63.

Rosalita, Syam, H., Fadilah, R. 2018. Pengaruh perendaman dengan asam jeruk nipis dan air cucian beras terhadap kualitas organoleptik puding rumput laut (eucheuma cottonii). Jurnal Pendidikan Teknologi Pertanian 4(9): 92-103. DOI: 10.26858/jptp.v4i0.6917.

Saharuddin, Amir, S., Said, M., Rosmina. 2018. Hubungan pola konsumsi natrium dan kalium dengan kejadian hipertensi di puskesmas paccerakkang makassar. Berita Kedokteran $\begin{array}{lll}\text { Masyarakat } 34(5): 1-7 . & \text { DOI: }\end{array}$ 10.22146/bkm.35451.

Sandulachi, E., Tatarov, P.G. 2012. Water activity concept and its role in strawberries food. Chemistry Journal of Moldova 7(2):103-115. DOI:10.19261/cjm.2012.07(2).07.

Sedjati, S., Suryono, S., Santosa, A., Supriyantini, E., Ridlo, A. 2017. Aktivitas antioksidan dan kandungan senyawa fenolik makroalga coklat sargassum sp. Jurnal Kelautan Tropis 20(2): 124. DOI: 10.14710/jkt.v20i2.1737.

Suryono, C., Ningrum, L., Dewi, T. R. 2018. Uji kesukaan dan organoleptik terhadap 5 kemasan dan produk kepulauan seribu secara deskriptif. Jurnal Pariwisata 5(2):95-106. DOI:10.31311/par.v5i2.3526.

Susanti, S., Arifan, F., Murni, Silviana, A. 2020. Karakteristik kimia dan mikrobiologi makanan ringan khas pemalang ogel ogel. Jurnal Aplikasi Teknologi Pangan 9(2):44-49. DOI:10.17728/jatp.3296.

Tamimi, A. A., Afifah, D. N., Fitranti, D. Y., Dieny, F. F. 2019. Pengaruh proporsi bahan terhadap daya terima agar-agar dengan penambahan kulit jeruk dan kulit semangka. Journal of Nutrition College 8(2):53-57. DOI:10.14710/jnc.v8i2.23813.

Uher, Anton, Ivana Mezeyova, Alzbeta,H., Miroslav Slosar. 2017. Impact of nutrition on the quality and quantity of cauliflower florets anton uher. Potravinarstvo Slovak Journal of Science 11(1):113-19. DOI: 10.5219/723.

Utama, C.S., Zuprizal, Hanim, C., Wihandoyo. 2019. Pengaruh lama autoclave terhadap kualitas kimia wheat pollard yang berpotensi sebagai prebiotik. Jurnal Aplikasi Teknologi Pangan 8(3):113-122. DOI:10.17728/jatp.5262.

Widyastuti, Desfita, D. 2020. Formulasi lotion ekstrak etanol buah stroberi (Fragaria $s p$ ) sebagai antioksidan dan tabir surya. Jurnal Farmasi dan Kesehatan 10(2):120-127. DOI:10.36434/scientia.v10i2.228.

Yosika, G.F., Sukoco, P., Pranoto, A., Purwoto, S.P. 2020. Penurunan malondialdehyde serum setelah latihan interval dan continuous di pagi hari pada perempuan obesitas. Jurnal Penelitian Pembelajaran 6(2):288-303. DOI:10.29407/js_unpgri.vi.14289.

Zadeh, Kalantar, Kamyar, Denis, F. 2017. Nutritional management of chronic kidney disease. New England Journal of Medicine 377(18): 17651776. DOI: 10.1056/NEJMra1700312.

Zurriyati, Y., Dahono. 2016. Keragaman sumber daya genetik tanaman buah-buahan eksotik di kabupaten bintan, provinsi kepulauan riau. Buletin PlasmaNutfah 22(1):11-20. DOI:10.21082/blpn.v22n1.2016. 